UDC 591.5: 594.32

https://doi.org/10.33989/2414-9810.2019.5.1.195127

\author{
A. P. Stadnychenko ${ }^{1}$, O. I. Uvayeva ${ }^{2}$, D. A. Vyskushenko ${ }^{3}$ \\ 1,3 Zhytomyr Ivan Franko State University \\ 40, Velyka Berdychivska Str., Zhytomyr, Ukraine, 10008 \\ 3bio-2016@ukr.net \\ 'ORCID 0000-0003-1894-0386 \\ ${ }^{3}$ ORCID 0000-0002-1233-7650 \\ 2Zhytomyr Polytechnic State University \\ 103, Chudnivska Str., Zhytomyr, Ukraine, 10005 \\ 2bio-2016@ukr.net \\ ²ORCID 0000-0003-1894-0386
}

\title{
THE INFLUENCE OF DETERGENTS ON THE CILIA LOCOMOTION ACTIVITY OF EPITHELIUM IN SINANODONTA WOODIANA (MOLLUSCA, UNION- IDAE)
}

The influence of one of the most popular detergent "Ushasty nian» ("Vinnitsapobutkhim», Ukraine) in concentrations of $3,6,12,24$, and $48 \mathrm{mg} / \mathrm{dm} 3$ on the duration and beat frequency of the glimmeral epithelium cilia of the gill apparatus of male, female and hermaphrodite Sinanodonta woodiana (Lea, 1834) specimens was investigated. The damaging effect on the viability of these mol-lusks, including the locomotive activity of the frontal cilia of their gill glimmeral epithelium depends on the toxic factor levels. In the toxicological study, the pathological process in mollusks shortly de-veloped in consequent five stages in two days. At 3 and $6 \mathrm{mg} / \mathrm{dm} 3$ concentrations of detergent, the signs observed in all three categories of molluscs included in vitro increased duration of locomotion and beat frequency of the glimmeral epithelium cilia. That state of experimental molluscs corresponds with the stimulation stage of pathological process induced by toxicological poisoning. Aforemen-tioned changes are the signs of adaptive protection process aimed to counteract the damage inflicted by the toxic substance. At 12 and 24 $\mathrm{mg} / \mathrm{dm} 3$ of detergent, the molluscs quickly entered the depres-sion stage of the pathological process. It manifests as a statistically significant sharp decrease of du-ration of activity and beat frequency of glimmeral epithelium cilia. At $24 \mathrm{mg} / \mathrm{dm} 3$ of toxicant, towards the end of exposure that stage was superseded by the sublethal stage. The latter is charac-terized by complete destruction of respiratory epithelium, maximum oedema of body tissues (espe-cially in the foot), loss of locomotion, and almost total loss of tactile sensitivity. At $48 \mathrm{mg} / \mathrm{dm} 3$ of toxicant, the sequence of depression, sublethal and lethal stages is realized quickly.

Key words: Sinanodonta woodiana, detergent, gills, glimmeral epithelium, activity.

Introduction. The human impact on the biosphere significantly grew to the $21^{\text {st }}$ century. One of its facets is aquatic pollution by various matters contained in industrial and domestic waste waters. Among the different components there are detergents or surface-active substances (SAS) which target the respiratory glimmeral epithelium of the gill apparatus of all gill-breathing organisms, affecting both salt- (Frid, \& Caswell, 2017) and freshwater (Дудник, \&Евтушенко, 2013; Метелев, Канаев, \& Дзасохова, 1971) animals. The SAS-induced damage level is conditioned by the toxicant concentration and chemical structure, and by the tolerance and physiological state of the exposed animals. Already there are several reports of SAS inhibiting the filtration activity of bivalve (primarily saltwater) molluscs (Marin et al., 1994; Ostroumov, 2009; Ostroumov, 2006).

First decades of the $21^{\text {st }}$ century were marked by the occurrence and rapid expansion in Ukraine (northern wards region from Black Sea, Transcarpathia) of the chinese pond mussel Sinanodonta woodiana (Lea, 1834). This species most probably occurred in Ukraine via Danube invasive corridor from the water network (Сон, 2007; Янович, \& Пампура, 2011). This mollusk has a wide ecological valence which allowed it the fast expansion in the European continental waters and worldwide. The successful persistence of $S$. woodiana populations in Ukraine will, supposedly, largely depend on the species resistance to the impact of pollutants in its natural waters, including various surfactants. The significance of this danger is evidenced by the fact that, despite the current MPC standards for surfactants $0,1 \mathrm{mg} / \mathrm{dm}^{3}$ for anion-active and $0,012 \mathrm{mg} / \mathrm{dm}^{3}$ for cation ionic pollutants, their content in natural waters of several Ukrainian regions at the beginning of the $21^{\text {st }}$ century became several times higher than that (Ситник та ін., 2001).

The aim of the present work was to find out the peculiarities of the detergent's effect on the duration of activity and beat frequency of the frontal glimmeral epithelium cilia of S. woodiana in vitro in norm and under exposure to high SAS concentrations. Solving this problem is important because the functionality of respiratory gill epithelium in S. woodiana and other Bivalvia conditions, to some degree, all their basic life support functions: breathing, feeding, excretion, reproduction. The epithelial functionality is regulated by a mechanism determining the organism's general reaction. Until now, S. woodiana was not studied in this aspect. 
Material and methods. Material is 342 specimens of $S$. woodiana (shell length 12,9-16,1 cm, shell height 8,6-9,7 cm), collected in the Danube lower reaches (Vilkovo, Odessa region) in June, 2011. In the laboratory the animals were acclimated for 15 days. They were kept in aquariums (50 and 100 liters, 1 specimen per 10 liters). The keeping conditions were as follows: water temperature $18-20^{\circ} \mathrm{C} ; \mathrm{pH} 7,4-8,6$; oxygenation $8,5-9,3 \mathrm{mg} \mathrm{O} / \mathrm{dm}^{3}$. The culture medium was changed daily. The mollusks were regularly fed (crushed dry fish food, ground yolk of steeply cooked chicken eggs).

The acclimated specimens were used in a two-step toxicological essay according to the standard technique (Алексеев, 1981). The toxicant was modeled by the detergent «Ushasty nian» («Vinnitsapobutkhim»). In a preliminary experiment it was established that the main toxicological indicators for $S$. woodiana are $L C_{0}=0,1$ and $L C_{100}=100 \mathrm{mg} / \mathrm{dm}^{3}$. Then graphically by the sliding curve method $L_{50}$ was estimated to be $50 \mathrm{mg} / \mathrm{dm}^{3}$. In the $\mathrm{LC}_{0} \mathrm{LC}_{50}$ range, five concentrations were chosen for the main experiment. The duration of each of the two experiments was two days. Each experiment was controlled.

The duration and frequency of ciliary beats of the frontal glimmeral epithelium of the S. woodiana gill apparatus were determined at temporary micropreparations done according to E. A. Veselov (1952), using the BIOLAM microscope $(\times 203$ and $\times 450)$ in triplicate, closing the iris diaphragm to weak light. Mollusk sex was determined according to (Шкорбатова, \& Старобогатова, 1990).

The quantitative results of the experiments were processed by the methods of basic variation statistics (Крамаренко, 2003).

Results and discussion. The results of the main toxicological essay are given in Table. According to them, under $3 \mathrm{mg} / \mathrm{dm}^{3} \mathrm{SAS}$ in the medium, the male, female and hermaphrodite S. woodiana specimens are characterized with increasing activity of the gill glimmeral epithelium and its ciliary beat frequency. Under $6 \mathrm{mg} / \mathrm{dm}^{3}$ SAS these changes become statistically significant $(p<0,01)$. The increased ciliary activity is a manifestation of the physiological-biochemical protective-adaptive process aimed at counteracting the damaging effect of the toxicant. It is known (Веселов, 1968) that the animal hydrobionts exposed to pollutants, depending on the toxicants' nature and concentration in the medium, duration of exposure, and resistance levels, suffer the phasic pathological process of poisoning. Each phase is characterized by specific complex of symptoms.

Physiological state of $S$. woodiana under 3 and $6 \mathrm{mg} / \mathrm{dm}^{3}$ SAS in the medium corresponds to that which is characteristic for the stage of stimulation. This follows from the aforementioned increased activity of their respiratory glimmeral epithelium, and from the weak mucus secretion by the frontal gill epithelium, which is a fast protective reaction demonstrated by the majority of the specimens. Even a thin mucus layer to some degree obstructs the SAS diffusion to the animal organisms and protects their gill respiratory epithelium from damage.

In the solution containing $12 \mathrm{mg} / \mathrm{dm}^{3} \mathrm{SAS}$, the experimental animals enter the depression phase of poisoning. This so-called "early" depression manifests by statistically significant $(p<0,01)$ slowed ciliary activity of glimmeral epithelium: the beat duration and frequency are reduced by 20 and $10 \%$, respectively.

This signifies a certain decrease of overall metabolism of $S$. woodiana which is however not lethal for them (100\% survival of exposed specimens). The levels of mucus secretion by skin integument and gill apparatus rise under these conditions. There are areas of fine sparse pastiness indicating the started swelling of body tissues.

The detergent effect on locomotive ciliary activity of the glimmeral epithelium of $S$. woodiana gill apparatus

\begin{tabular}{|c|c|c|c|c|c|c|}
\hline \multirow[b]{2}{*}{ Material } & \multicolumn{3}{|c|}{ Locomotion duration (hr) } & \multicolumn{3}{|c|}{ Beat frequency (number per minute) } \\
\hline & $\mathrm{n}$ & $\lim$ & $\begin{array}{c}\mathrm{M} \pm \mathrm{m} \\
\mathrm{CV}\end{array}$ & $\mathrm{n}$ & $\lim$ & $\begin{array}{c}\mathrm{M} \pm \mathrm{m} \\
\mathrm{CV}\end{array}$ \\
\hline \multicolumn{7}{|c|}{ Control } \\
\hline Males & 10 & $109-333$ & $\begin{array}{c}240.1 \pm 11.1 \\
7.1\end{array}$ & 11 & $241-330$ & $\begin{array}{c}316.2 \pm 2.4 \\
5.6\end{array}$ \\
\hline Females & 10 & $121-340$ & $\begin{array}{c}229.2 \pm 9.3 \\
4.9\end{array}$ & 12 & $238-341$ & $\begin{array}{c}325.1 \pm 3.7 \\
4.8\end{array}$ \\
\hline Hermaphrodites & 6 & $116-329$ & $\begin{array}{c}231.0 \pm 8.17 \\
9.9\end{array}$ & 7 & $222-339$ & $\begin{array}{c}320.4 \pm 2.2 \\
2.5\end{array}$ \\
\hline \multicolumn{7}{|c|}{$3 \mathrm{mg} / \mathrm{dm}^{3}$} \\
\hline Males & 11 & $117-345$ & $\begin{array}{c}258.3 \pm 12.15 \\
11.7\end{array}$ & 11 & $237-340$ & $\begin{array}{c}329.1 \pm 3.6 \\
3.7\end{array}$ \\
\hline Females & 10 & $122-361$ & $\begin{array}{c}261.4 \pm 11.1 \\
11.1\end{array}$ & 11 & $243-359$ & $\begin{array}{c}359.6 \pm 9.3 \\
4.1\end{array}$ \\
\hline Hermaphrodites & 6 & $129-351$ & $\begin{array}{c}250.1 \pm 18.1 \\
5.2\end{array}$ & 6 & $228-361$ & $\begin{array}{c}348.3 \pm 5.0 \\
4.4\end{array}$ \\
\hline \multicolumn{7}{|c|}{$6 \mathrm{mg} / \mathrm{dm}^{3}$} \\
\hline Males & 11 & $122-353$ & $\begin{array}{c}299.2 \pm 20.3 \\
10.2\end{array}$ & 13 & $251-419$ & $\begin{array}{c}399.3 \pm 3.2 \\
4.6\end{array}$ \\
\hline Females & 12 & $130-359$ & $\begin{array}{c}311.1 \pm 18.2 \\
13.1\end{array}$ & 14 & $236-432$ & $\begin{array}{c}401.4 \pm 4.7 \\
8.1\end{array}$ \\
\hline
\end{tabular}




\begin{tabular}{|c|c|c|c|c|c|c|}
\hline Hermaphrodites & 7 & $137-347$ & $\begin{array}{c}321.2 \pm 15.1 \\
8.7\end{array}$ & 6 & $198-440$ & $\begin{array}{c}409.5 \pm 6.2 \\
6.3\end{array}$ \\
\hline \multicolumn{7}{|c|}{$12 \mathrm{mg} / \mathrm{dm}^{3}$} \\
\hline Males & 10 & $105-308$ & $\begin{array}{c}205.0 \pm 15.2 \\
10.3\end{array}$ & 13 & $227-331$ & $\begin{array}{c}301.2 \pm 5.5 \\
4.1\end{array}$ \\
\hline Females & 12 & $110-316$ & $\begin{array}{c}200.1 \pm 18.3 \\
17.3\end{array}$ & 11 & $219-328$ & $\begin{array}{c}300.3 \pm 3.8 \\
5.4\end{array}$ \\
\hline Hermaphrodites & 6 & $102-312$ & $\begin{array}{c}198.1 \pm 11.1 \\
13.1\end{array}$ & 7 & $220-336$ & $\begin{array}{c}298.7 \pm 4.1 \\
3.3\end{array}$ \\
\hline \multicolumn{7}{|c|}{$24 \mathrm{mg} / \mathrm{dm}^{3}$} \\
\hline Males & 12 & $89-157$ & $\begin{array}{c}120.2 \pm 9.1 \\
6.8\end{array}$ & 10 & $92-122$ & $\begin{array}{c}106.2 \pm 2.9 \\
3.0\end{array}$ \\
\hline Females & 13 & $82-149$ & $\begin{array}{c}116.1 \pm 10.3 \\
12.5\end{array}$ & 10 & $89-127$ & $\begin{array}{c}99.9 \pm 1.4 \\
6.3\end{array}$ \\
\hline Hermaphrodites & 7 & $77-137$ & $\begin{array}{c}111.2 \pm 9.2 \\
11.1\end{array}$ & 6 & $91-129$ & $\begin{array}{c}102.3 \pm 3.3 \\
4.1\end{array}$ \\
\hline \multicolumn{7}{|c|}{$48 \mathrm{mg} / \mathrm{dm}^{3}$} \\
\hline Males & 10 & $38-51$ & $\begin{array}{c}44.0 \pm 6.1 \\
14.1\end{array}$ & 10 & $28-51$ & $\begin{array}{c}43.0 \pm 1.1 \\
2.2\end{array}$ \\
\hline Females & 11 & $34-46$ & $\begin{array}{c}33.3 \pm 7.1 \\
8.8\end{array}$ & 12 & $26-48$ & $\begin{array}{c}38.7 \pm 3.0 \\
4.7\end{array}$ \\
\hline Hermaphrodites & 6 & $29-39$ & $\begin{array}{c}35.1 \pm 6.2 \\
12.3\end{array}$ & 7 & $23-44$ & $\begin{array}{c}34.3 \pm 2.1 \\
5.2\end{array}$ \\
\hline
\end{tabular}

At $24 \mathrm{mg} / \mathrm{dm} 3$ after $9-12$ hours of exposure, the experimental S. woodiana specimens are at the "deep" depression stage. The complex of relevant symptoms includes intense mucus excretion by the gills, emerging foci of destruction of the respiratory epithelium with developing lesions and hemorrhages, increasingly swollen body tissues, and reduced tactile sensitivity. However at the end of the first day of exposure all specimens retain viability despite the failed respiratory function of the gill apparatus epithelium. It is assumed (Маляревская, \& Карасина, 1983; Маляревская, 1985) that at this stage of the pathological process the mollusks usually turn from the aerobic to anaerobic method for the cleavage of glycogen, their universal energy substrate. This physiological and biochemical protective measure allows them to remain viable in conditions of anoxia for at least some time. The duration of activity of glimmeral epithelium on the areas of $S$. woodiana body where it still remains decreases twofold, and its ciliary beat frequency decreases 3.1 times compared to norm. At the second half of the first day of exposure, all S. woodiana specimens enter the sublethal poisoning stage. It is characterized by completely damaged frontal ciliated epithelium of the gills. Due to increasingly swelled body tissues the foot is so enlarged that it does not fit in the shell and hangs out far beyond the valve edges. The medium contains copious excrements simultaneously ejected by S. woodiana experimental specimens. At the second day of experiment, all specimens are completely immobile however they still retain slight tactile sensitivity. At the end of exposure, $22,8 \%$ of animals develop the last poisoning stage, lethal, manifesting in true shock and complete lack of tactile sensitivity. In mollusks, it manifests as developing true shock symptoms and full loss of the tactile sensitivity.

In the medium containing $48 \mathrm{mg} / \mathrm{dm}^{3}$ experimental animals experienced the three highest degrees of intoxication: depression, sublethal and lethal stages. At "deep" depression stage the duration of activity of gill glimmeral epithelium decreases 6,2 times and ciliary beat frequency in 8,3 times.

The nature of the changes in the ciliary activity indices of the frontal ciliated epithelium of $S$. woodiana gill apparatus depends on the level of surfactant content in its environment, which is consistent with the concept of G. Selye (1982). According to it, small stresses («eustresses») in contrast to overexertions («distresses») optimize the vital activity of organisms, increasing their adaptive capacity with respect to new conditions. Our results indicate that for S. woodiana «eustresses» are surfactants in concentrations of 3 and $6 \mathrm{mg} / \mathrm{dm}^{3}$, while the higher concentrations of this pollutant must be characterized as «distresses».

Conclusions. The duration of activity and ciliary beat frequency of the glimmeral epithelium of S. woodiana gill apparatus increase at 3 and $6 \mathrm{mg} / \mathrm{dm}^{3}$ of the «Ushasty nian» detergent in the environment. This protective adaptation is characteristic for the stimulation stage of the intoxication process.

The duration of activity of the gill epithelium and its beat frequency decline in experimental animals, inversely related to the growing content of the toxic substance $\left(12,24,48 \mathrm{mg} / \mathrm{dm}^{3}\right)$. The intoxication process in the affected specimens develops into the depression, sublethal and lethal stages.

\section{Список використаної літератури:}

Алексеев В. А. Основные принципы сравнительно-токсикологического эксперимента. Гидробиологический журнал. 1981. Т. 71, № 3. С. 92-100.

Веселов Е. А. Биологические тесты при санитарно-биологическом изучении водоемов. Жизнь пресных вод СССР. Москва ; Ленинград : Изд-во АН СССР, 1959. Т. 4, кн. 2. С. 7-37. 
Веселов Е. А. Основные фазы действия токсических веществ на организмы. Тезы докладов Всесоюзной научной конференциии по вопросам водной токсикологии. Москва : Наука, 1968. С. 15-16.

Вивчення еколого-токсикологічного стану річок Прип'ять та Стохід / Ю. М. Ситник та ін. Вісник Житомирського педагогічного університету. 2001. Вип. 8. С. 244-248.

Дудник, С. В., Свтушенко, М. Ю. Водна токсикологія: основні теоретичні положення та їхне практичне застосування. 2013. Київ : Вид-во Укр. фітосоціологічного центру. 297 с.

Крамаренко С. С. Математичні методи в екології. Миколаїв, 2003. 232 с.

Маляревская А. Я., Карасина Ф. М. Влияние некоторых поверхностно-активных веществ на гидробионтов. Гидробиологический журнал. 1983. Т. 19, № 5. С. 84-90.

Маляревская А. Я. Биохимические механизмы адаптации гидробионтов к токсическим веществам. Гидробиологический журнал. 1985. Т. 21, № 3. С. 70-82.

Метелев В. В., Канаев А. И., Дзасохова Н. Г. Водная токсикология. Москва : Колос, 1971. 247 с.

Методы изучения двустворчатых модлюсков / под ред.: Г. А. Шкорбатова, Я. И. Старобогатова. Аенинград : 3ИН, 1990. 205 c.

Селье Г. Стресс без дистресса. Москва : Прогресс, 1982. 352 с.

Сон М. О. Молдюски-вселенцы в пресных и солоноватых водах Северного Причерноморья. Одесса, 2007. 132 с.

Янович А. М., Пампура М. М. Новая находка моллюска-вселенца Sinanodonta woodiana Lea, 1834 (Mollusca: Bivalvia: Unionidae) в Украине. Вестник зоологии. 2011. Вып. 45 (2). С. 186.

Effects and fate of sediment-sorbed linear alkylbenzene sulphonate (LAS) on the bivalve mollusc mytilus galloprovincialis Lmk / M. G. Marin et al. Water Research. 1994. Vol. 28 (1). P. 85-90. DOI: 10.1016/0043-1354(94)90122-8.

Frid C. L. J., Caswell B. A. Marine pollution. Oxford : Oxford University Press, 2017. 268 p. DOI https://doi.org/10.1111/maec.12487

Ostroumov, S. A. (2003). Influence of Some Amphyphilic Substances and Mixtures on Marine Mollusks. Hydrobiological Journal. 2009. Vol. 39(4). P. 97-101, 75-80.

Ostroumov, S. A. Biological Effects of Surfactants. London; New York, 2006. 279 p. DOI: 10.13140/RG.2.1.1619.9209

\section{References}

Alekseev, V. A. (1981). Osnovnye printsipy sravnitel'no-toksikologicheskogo eksperimenta [Essential principles of the comparative-toxical experiments]. Hydrobiological Journal, 71(3), 92-100 [in Russian].

Dudnyk, S. V., \& Yevtushenko, M. Yu. (2013). Vodna toksykolohiia: osnovni teoretychni polozhennia ta yikhnie praktychne zastosuvannia [Water toxicology: basic theoretical positions and their practical application]. Kyiv: Vyd-vo Ukr. fitosotsiolohichnoho tsentru [in Ukrainian].

Frid, C.L.J., Caswell, B.A. (2017). Marine pollution. Oxford: Oxford University Press. doi https://doi.org/10.1111/maec.12487

Kramarenko, S. S. (2003). Matematychni metody v ekolohii [Mathematical methods in ecology]. Mykolaiv [in Ukrainian].

Malyarevskaya, A. Ya. (1985). Biokhimicheskie mekhanizmy adaptatsii gidrobiontov k toksicheskim veshchestvam [Biochemical mechanisms of adaptations the hydrobionts to toxical substances]. Hydrobiological Journal, 21(3), 70-82 [in Russian].

Malyarevskaya, A. Ya., \& Karasina, F. M. (1983). Vliyanie nekotorykh poverkhnostno-aktivnykh veshchestv na gidrobiontov [The influence of some surface-active substances on the hydrobiontes]. Hydrobiological Journal, 19 (5), 84-90 [in Russian].

Marin, M. G., Pivotti, L., Campesan, G., Turchetto, M., \& Tallandini, L. (1994). Effects and fate of sediment-sorbed linear alkylbenzene sulphonate (LAS) on the bivalve mollusc mytilus galloprovincialis Lmk. Water Research, 28(1), 85-90. doi: 10.1016/0043-1354(94)90122-8.

Metelev, V. V., Kanaev, A. I., \& Dzasokhova, N. G. Vodnaya toksikologiya [Water toxicology]. Moskva: Kolos [in Russian].

Ostroumov, S. A. (2003). Influence of Some Amphyphilic Substances and Mixtures on Marine Mollusks. Hydrobiological Journal, 39(4), 97-101, 75-80. doi: 10.1615/HydrobJ.v39.i4.100

Ostroumov, S. A. (2006). Biological Effects of Surfactants. London; New York, 2006. doi: 10.13140/RG.2.1.1619.9209

Sel'e, G. (1982). Stress bez distressa [Stress without distress]. Moskva: Progress [in Russian].

Shkorbatova, G. L., \& Starobogatova, Ya. I. (Ed.). (1990). Metody izucheniya dvustvorchatykh mollyuskov [Methods of studies of bivalve molluscs]. Leningrad: ZIN [in Russian].

Son, M. O. (2007). Mollyuski-vselentsy v presnykh i solonovatykh vodakh Severnogo Prichernomor'ya [The adventurer mollusks into fresh- and salinewater by northerwards region from Black Sea]. Odessa [in Russian].

Sytnyk, Yu. M., Arsan, O. M., Kyrychuk, H. Ye., \& Yanovych, L. M. (2001). Vyvchennia ekoloho-toksykolohichnoho stanu richok Pryp'iat ta Stokhid. [Investigation of Ecology-toxicological State of the Pripyat' and Stokhid Rivers]. Zhytomyr Ivan Franko State University Journal, 8, 244-248 [in Ukrainian].

Veselov E. A., (1968). Osnovnye fazy deistviya toksicheskikh veshchestv na organizmy [Principal phases of action by toxical substances on the organisms]. In Tezy dokladov Vsesoyuznoi nauchnoi konferentsii po voprosam vodnoi toksikologii [Abstracts of the All-Union Scientific Conference on Aquatic Toxicology] (pp. 15-16). Moskva: Nauka [in Russian].

Veselov, E. A. (1959). Biologicheskie testy pri sanitarno-biologicheskom izuchenii vodoemov [Biological tests at sanitary-biological investigation of the water reservoirs]. In V. I. Zhadin, \& E. N. Pavlovskii (Eds.), Zhizn' presnykh vod SSSR [Life of Freshwaters by USSR] (Vol. 4, pt. 2, pp. 7-37). Moskva; Leningrad: Izd-vo AN SSSR [in Russian].

Yanovich L. M., \& Pampura, M. M. (2011). Novaya nakhodka mollyuska-vselentsa Sinanodonta woodiana Lea, 1834 (Mollusca: Bivalvia: Unionidae) v Ukraine. [New find of invasive mollusk Sinanodonta woodiana Lea, 1834 (Mollusca: Bivalvia: Unionidae) in Ukraine]. Vestnik Zoologii,45(2), 186 [in Russian]. 